\title{
Hyperventilation-induced asthma: evidence for two mechanisms
}

\author{
NM WILSON, PJ BARNES, H VICKERS, M SILVERMAN \\ Departments of Paediatrics and Neonatal Medicine and of Medicine, Hammersmith Hospital, London
}

\begin{abstract}
The mechanism by which airway cooling induces airflow obstruction in asthmatic subjects has not yet been established. Using a pair of isocapnic hyperventilation challenges, with a 40-minute interval, we looked for the presence of a refractory period in 19 asthmatic patients (aged 9-18 years). The subjects fell into two groups. The eight in the "non-refractory" group showed less than a $25 \%$ reduction in response to the second challenge, but the 11 in the "refractory" group showed at least a $35 \%$ reduction. Twelve subjects also performed a hyperventilation challenge after cholinergic blockade with inhaled ipratropium bromide. In five, in whom no refractoriness after hyperventilation was seen, there was a significant protection from cholinergic blockade $(p<0.05)$. In these a vagal (cholinergic) reflex seems likely. The remaining seven, who had a refractory period, received no significant protection from cholinergic blockade and therefore no evidence for the presence of any cholinergic mechanism. We conclude that two mechanisms are responsible for hyperventilation-induced asthma, one of which is a vagal reflex while mediator release may be the other.
\end{abstract}

The initiating stimulus in exercise-induced asthma is airway cooling brought about by heat and water loss during the increased ventilation of exercise. ${ }^{12}$ Hyperventilation alone produces airflow obstruction equivalent to that induced by exercise when ventilation and inspired air conditions are the same. ${ }^{3}$ The mechanism by which airway cooling leads to bronchoconstriction is, however, uncertain. In many studies anticholinergic drugs have been found to inhibit exercise-induced asthma in about half the asthmatic subjects tested, suggesting that a vagal reflex may play a part..$^{4-8}$ As only a proportion of subjects are protected by cholinergic blockade, some additional mechanism, such as mast-cell mediator release, may also be concerned. This idea is supported by the finding that cromoglycate, which stabilises mast cells in vitro, ${ }^{9}$ has a protective effect in most people with exercise-induced asthma. ${ }^{5710}$ Further circumstantial evidence for mediator release in exercise-induced asthma is provided by the refractory period, during which a second exercise test produces less airflow obstruction than the first. ${ }^{11}$ It may last up to two hours and one possible explanation is that mast cells require time to regranu-

Address for reprint requests: Dr NM Wilson, Institute of Child Health, Hammersmith Hospital, Du Cane Road, London W12 oHS. late. ${ }^{12}$ Another is that concentrations of catecholamines rise during exercise and, by increasing cyclic AMP in airways, temporarily protect against exercise-induced asthma. ${ }^{13}$ If the latter explanation were true no refractory period would be expected after hyperventilation-induced asthma as no rise in circulating catecholamines has been found with hyperventilation at rest. ${ }^{14}$ Possibly both a vagal reflex and mediator release occur after airway cooling, although either may predominate in different patients or even in the same patient at different times.

We looked for the presence of a refractory period after hyperventilation-induced asthma, as evidence of possible mediator release. We have related the presence or absence of refractoriness to the effect of cholinergic blockade on hyperventilation-induced asthma to determine the role of a vagal reflex mechanism.

\section{Methods}

Nineteen patients were selected from the paediatric and adult asthma clinics on the basis of a history of exercise-induced asthma (table). All had multiple positive immediate reactions to skin prick tests for common allergens. Their clinical severity ranged 
Data on the asthmatic patients studied

\begin{tabular}{|c|c|c|c|c|c|c|c|c|c|}
\hline \multirow{3}{*}{$\begin{array}{l}\text { Patient } \\
\text { No }\end{array}$} & \multirow{3}{*}{$\begin{array}{l}\text { Predicted } \\
\text { PEFR } \\
(1 / \text { min })\end{array}$} & \multicolumn{4}{|l|}{ Day 1} & \multicolumn{4}{|l|}{ Day 2} \\
\hline & & \multicolumn{2}{|l|}{$H V_{1}$} & \multicolumn{2}{|l|}{$H V_{2}$} & \multicolumn{2}{|l|}{$H V_{C}$} & \multicolumn{2}{|l|}{$H V_{1 B}$} \\
\hline & & $\boldsymbol{B}$ & $\boldsymbol{R}$ & $\boldsymbol{B}$ & $\boldsymbol{R}$ & $\boldsymbol{B}$ & $R$ & $\boldsymbol{B}$ & $\boldsymbol{R}$ \\
\hline \multicolumn{10}{|c|}{ Refractory group } \\
\hline $\begin{array}{l}1 \\
2 \\
3\end{array}$ & $\begin{array}{l}335 \\
415\end{array}$ & $\begin{array}{l}250 \\
340 \\
305\end{array}$ & $\begin{array}{r}95 \\
255\end{array}$ & $\begin{array}{l}200 \\
325 \\
325\end{array}$ & $\begin{array}{l}200 \\
300\end{array}$ & $\begin{array}{l}215 \\
310\end{array}$ & $\begin{array}{l}160 \\
235\end{array}$ & $\begin{array}{l}215 \\
330\end{array}$ & $\begin{array}{l}165 \\
240\end{array}$ \\
\hline 4 & $\begin{array}{l}420 \\
350\end{array}$ & $\begin{array}{l}395 \\
265\end{array}$ & $\begin{array}{r}210 \\
95\end{array}$ & $\begin{array}{l}325 \\
195\end{array}$ & $\begin{array}{l}285 \\
130\end{array}$ & 345 & 225 & 400 & 270 \\
\hline $\begin{array}{l}5 \\
6\end{array}$ & $\begin{array}{l}450 \\
430\end{array}$ & $\begin{array}{l}510 \\
330\end{array}$ & $\begin{array}{l}335 \\
115\end{array}$ & $\begin{array}{l}425 \\
285\end{array}$ & 360 & & & & \\
\hline$\stackrel{6}{7}$ & $\begin{array}{l}430 \\
450\end{array}$ & $\begin{array}{l}330 \\
370\end{array}$ & $\begin{array}{l}115 \\
200\end{array}$ & $\begin{array}{l}285 \\
350\end{array}$ & $\begin{array}{l}200 \\
270\end{array}$ & 370 & 200 & 395 & 240 \\
\hline 8 & 375 & 365 & 160 & 340 & 245 & 360 & 255 & 370 & 245 \\
\hline 9 & 450 & 355 & 300 & 360 & 345 & 270 & 230 & 355 & 235 \\
\hline 10 & $\begin{array}{l}445 \\
370\end{array}$ & $\begin{array}{l}410 \\
280\end{array}$ & 335 & 420 & 380 & & & & \\
\hline $\begin{array}{l}11 \\
\text { Mean }\end{array}$ & $\begin{array}{l}370 \\
408\end{array}$ & $\begin{array}{l}280 \\
352\end{array}$ & $\begin{array}{l}180 \\
207\end{array}$ & $\begin{array}{l}255 \\
317\end{array}$ & 200 & 240 & 135 & 260 & 160 \\
\hline SEM & $\begin{array}{r}400 \\
13 \cdot 0\end{array}$ & $22 \cdot 3$ & $\begin{array}{r}207 \\
27.0\end{array}$ & $\begin{array}{r}317 \\
23.3\end{array}$ & $\begin{array}{c}265 \\
23.7\end{array}$ & $\begin{array}{l}310 \\
23.5\end{array}$ & $\begin{array}{l}205 \\
16.7\end{array}$ & $\begin{array}{l}332 \\
26.9\end{array}$ & $\begin{array}{c}220 \\
16 \cdot 2\end{array}$ \\
\hline \multicolumn{10}{|c|}{ Non-refractory group } \\
\hline 12 & $290^{\circ}$ & 285 & 235 & 285 & 245 & 270 & 223 & 315 & 300 \\
\hline $\begin{array}{l}13 \\
14\end{array}$ & $\begin{array}{l}330 \\
410\end{array}$ & $\begin{array}{l}225 \\
280\end{array}$ & $\begin{array}{l}120 \\
160\end{array}$ & $\begin{array}{l}250 \\
300\end{array}$ & $\begin{array}{l}110 \\
150\end{array}$ & & & & \\
\hline 15 & 300 & 375 & 290 & 400 & 315 & 360 & 280 & 395 & 380 \\
\hline 16 & 555 & 455 & 250 & 435 & 250 & 425 & 195 & 540 & 510 \\
\hline $\begin{array}{l}17 \\
18\end{array}$ & $\begin{array}{l}415 \\
330\end{array}$ & $\begin{array}{l}260 \\
245\end{array}$ & $\begin{array}{l}160 \\
125\end{array}$ & $\begin{array}{l}245 \\
260\end{array}$ & $\begin{array}{l}145 \\
120\end{array}$ & 420 & 335 & 430 & 400 \\
\hline 19 & 340 & 305 & 210 & 310 & 160 & 315 & 230 & 255 & 270 \\
\hline Mean & 371 & 304 & 194 & 311 & 162 & 358 & 253 & 387 & 372 \\
\hline SEM & $29 \cdot 1$ & $25 \cdot 3$ & 20.6 & $23 \cdot 5$ & $28 \cdot 1$ & 30 & $24 \cdot 8$ & 49.0 & $4 \overline{2} \cdot 1$ \\
\hline \multicolumn{10}{|c|}{ Total group } \\
\hline Mean & 393 & 332 & 202 & 315 & 232 & 325 & 225 & 355 & 285 \\
\hline SEM & $15 \cdot 1$ & $17 \cdot 6$ & $17 \cdot 8$ & $16 \cdot 6$ & $25 \cdot 5$ & 19.7 & $15 \cdot 1$ & 25.6 & $29 \cdot 1$ \\
\hline
\end{tabular}

PEFR-peak flow rate; $\mathrm{HV}_{1}, \mathrm{HV}_{2}$-first and second hyperventilation challenge tests with 40-minute interval; $\mathrm{HV}_{\mathrm{C}}, \mathrm{HV} \mathrm{B}_{\mathrm{B}}-$ control hyperventilation challenge test and test repeated after ipratropium bromide; B-baseline PEFR ( $1 / \min )$; $R$ - PEFR at maximum response (V/min).

from those taking occasional $\beta$-agonists to those needing an additional prophylactic agent such as cromoglycate, sustained-release aminophylline, or inhaled steroids. None was taking oral steroids. All drugs were discontinued for at least eight hours before the study and sustained-release aminophylline for 24 hours.

The study was approved by the ethics committee of the Hammersmith Hospital and all subjects and their parents gave their informed consent.

The hyperventilation was performed as previously described, ${ }^{3}$ the subject voluntarily hyperventilating for five minutes via a dry gas meter (Parkinson Cowan CD4), so that the rotation of the gas meter needle corresponded to the rotation of a superimposed motor-driven pointer, calibrated to give the required minute ventilation $(\dot{V})$. The target $\dot{V}$ was set at 20 times the FEV , although in some subjects with highly reactive airways a lower target was necessary. The same target was used for each subject with every study. End-tidal carbon dioxide $\left(\mathrm{P}_{\mathrm{ET}} \mathrm{CO}_{2}\right)$ was monitored (Capnograph, Godart) throughout the study and $100 \%$ carbon dioxide added to the inspired air so that $\mathrm{P}_{\mathrm{ET}} \mathrm{CO}_{2}$ was maintained at about $5 \mathrm{kPa}(37.5 \mathrm{~mm} \mathrm{Hg})$ throughout the hyperventilation. As the study was performed in an air-conditioned laboratory the inspired air temperature $\left(22 \pm 2^{\circ} \mathrm{C}\right)$ and relative humidity $(50 \pm 5 \%)$ were constant, so airway cooling was proportional to the $\mathrm{V}$ achieved. Peak expiratory flow rate (PEFR; Wright peak flow meter, Airmed, calibrated against a Rotameter flow meter) was determined in triplicate and the highest values were recorded, before and at the end of hyperventilation, at one, three, and five minutes after finishing, then every five minutes until spontaneous recovery occurred. The response (\% fall in PEFR) was taken as the lowest PEFR after the challenge, expressed as a percentage fall $I$ from the baseline value: ((Baseline PEFR - lowest PEFR)/baseline PEFR) $\times 100 \%$.

Subjects attended on two study days within 14 days. On the first day an initial hyperventilation $N$ challenge was performed and this was repeated $40 \mathrm{\omega}$ minutes later with the same target $\dot{\mathrm{V}}$. When PEFR was back to baseline value a methacholine inhala- $\bullet$ tion challenge was performed by the method that Cockcroft and colleagues have standardised for histamine inhalation. ${ }^{15}$ Methacholine, in doubling concentrations, was inhaled until PEFR had fallen by at least $20 \%$ from the value after inhalation of saline; 
the concentration causing a $20 \%$ fall $\left(\mathrm{PC}_{20}\right)$ was calculated. On the second day, an initial control hyperventilation was performed, with the same target $\mathrm{V}$ as on the first day. At least 60 minutes later subjects inhaled ipratropium bromide $(80 \mu \mathrm{g}$, four puffs) from a metered aerosol. Cholinergic blockade was ascertained 45 minutes after the ipratropium bromide by showing that no fall in PEFR was produced by the inhalation of methacholine at a concentration of at least four times the predetermined $\mathrm{PC}_{20}$. A second hyperventilation challenge, with matched target $\mathrm{V}$, took place 60 minutes after ipratropium bromide (two hours after the initial hyperventilation challenge to allow time for recovery from refractoriness). The results were analysed with paired and unpaired $t$ tests and correlations determined by the Rank Spearman correlation coefficient.

\section{Results}

\section{REPEATED HYPERVENTILATION}

There was a significant reduction in the mean response to a second challenge performed 40 minutes after the first $(p<0.01)$, although the $\dot{V}$ and the baseline PEFR were not significantly different between the two tests (table, fig 1). When the results of individual subjects were analysed, two groups could be differentiated on the basis of the reduction in response to the second challenge. A protection index was calculated that gave the reduction in response to the second hyperventilation challenge $\left(\mathrm{HV}_{2}\right)$ as a percentage of the initial response $\left(\mathrm{HV}_{1}\right):\left(\left(\%\right.\right.$ fall PEFR $\mathrm{HV}_{1}-\%$ fall $\left.\mathrm{HV}_{2}\right) /$ fall PEFR $\left.\mathrm{HV}_{1}\right) \times 100 \%$.

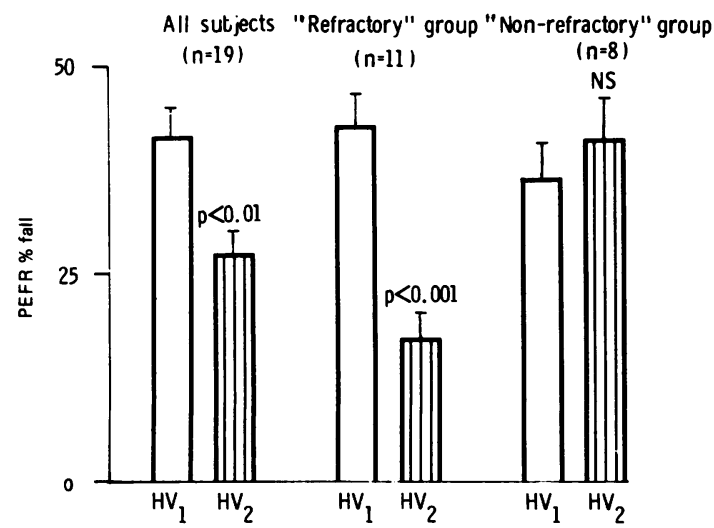

Fig 1 Mean responses to a second hyperventilation challenge $(\mathrm{HV})_{2} 40$ minutes after the first $(\mathrm{HV})$ for the whole group and for the two subgroups ("refractory" and "non-refractory").
Eleven subjects (the "refractory" group) were defined by a protection of $35 \%$ or more after the second challenge. The remaining eight subjects (the "non-refractory" group) had less than $25 \%$ protection. There was no significant difference in the ventilation achieved during the first and the second test in either group: refractory group $43 \pm 2 \cdot 2$ (mean \pm $\mathrm{SEM}, \mathrm{l} / \mathrm{min}$ ) and $41 \pm 2.0$; non-refractory group 41 \pm 1.7 and $40 \pm 1.7$ respectively. The baseline PEFR was significantly lower $(p<0.02)$ in the refractory group before the second hyperventilation challenge (table), indicating that these subjects had not fully recovered from the initial challenge by 40 minutes. There was no difference between the two groups in atopic state, clinical severity, baseline PEFR or the magnitude of the bronchoconstrictor response to hyperventilation.

In three patients showing a refractory period a third test 120 minutes after the first showed recovery of the response to hyperventilation.

\section{EFFECT OF CHOLINERGIC BLOCKADE}

In 12 subjects the effect of cholinergic blockade on hyperventilation-induced asthma was investigated. The presence of cholinergic blockade, produced by ipratropium bromide, was confirmed in all these patients by methacholine challenge. The methacholine $\mathrm{PC}_{20}$ of the subjects was $0.87 \pm 0.27$ $\mathrm{mg} / \mathrm{ml}$ (mean $\pm \mathrm{SEM}$ ). After ipratropium bromide, challenge with methacholine in a mean concentration of $3.88 \pm 0.83 \mathrm{mg} / \mathrm{ml}$ gave a fall in PEFR of 1.7 $\pm 1 \cdot 1 \%$, confirming effective cholinergic blockade. The five non-refractory subjects showed a significant reduction in the response to hyperventilation after ipratropium bromide $(p<0.05)$ but in the seven refractory subjects there was no difference between the results of the two tests (table, fig 2). In neither

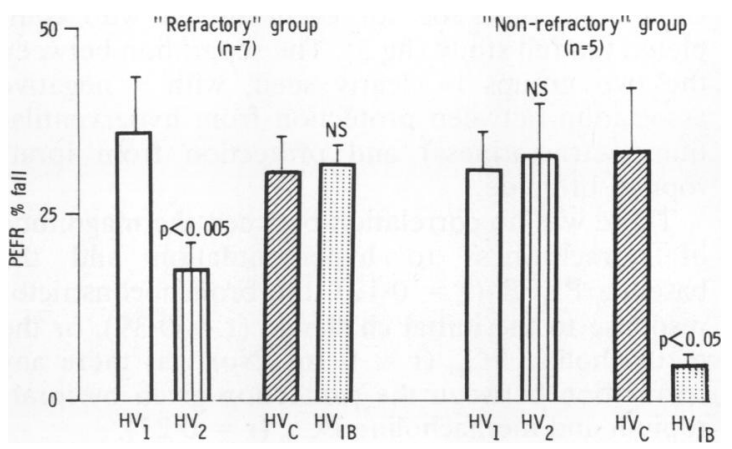

Fig 2 Mean responses to repeated hyperventilation challenge ( $H V_{1}$ and $\left.H V_{2}\right)$ in the two subgroups, compared with the protection afforded against hyperventilation challenge by inhalation of ipratropium bromide $\left(H V_{C}\right.$ compared with $H V_{I B}$ ). 


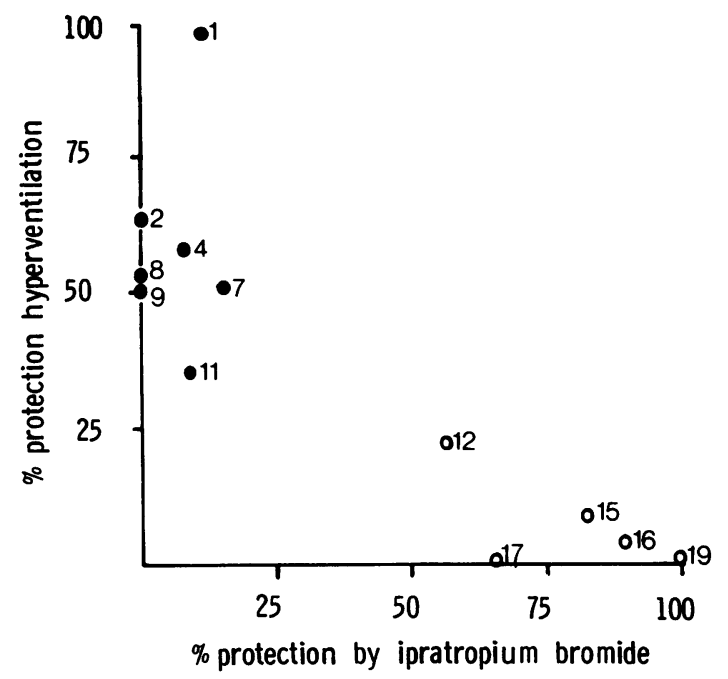

Fig 3 Relation between refractoriness to repeated hyperventilation challenge (\% protection hyperventilation) and inhibition of hyperventilation-induced asthma by ipratropium bromide (\% protection by ipratropium bromide) for 12 individual subjects. Numbers relate to the table. Closed circles indicate "refractory" subjects and open circles "non-refractory" subjects.

group of subjects was there any significant difference in $\dot{V}$ achieved between the pair of tests before and after cholinergic blockade: refractory group 42 \pm 8.2 (mean value $\pm \mathrm{SEM}, \mathrm{l} / \mathrm{min}$ ) and $40 \pm 7.4$; non-refractory group $43 \pm 2.9$ and $45 \pm 3.5$. The bronchodilator effect of ipratropium bromide was confirmed by the increase in baseline PEFR: refractory group $14.9 \pm 5.6 \%$; non-refractory group 19.0 $\pm \mathbf{4 . 8 5 \%}$.

The protection index for repeated hyperventilation was plotted against the protection index for cholinergic blockade for each subject who completed the full study (fig 3 ). The separation between the two groups is clearly seen, with a negative association between protection from hyperventilation (refractoriness) and protection from ipratropium bromide.

There was no correlation between the magnitude of refractoriness to hyperventilation and the baseline PEFR $(r=0 \cdot 12)$, the bronchoconstrictor response to the initial challenge $(r=0.39)$, or the methacholine $\mathrm{PC}_{20}(\mathrm{r}=0 \cdot 16)$. Nor was there any correlation between the protection given by ipratropium and methacholine $\mathrm{PC}_{20}(r=0 \cdot 27)$.

\section{REPRODUCIBILITY}

Nine subjects were tested for the presence of a refractory period after hyperventilation-induced asthma on more than one occasion, from two weeks up to 12 months after the original test. All five of those in the refractory group were again refractory but only two out of four in the non-refractory group remained non-refractory. One of these was the patient seen in fig 3 to have an intermediate response (subject No 12).

\section{Discussion}

Using isocapnic hyperventilation we could show in some but not all subjects a diminished bronchoconstrictor response to a second hyperventilation test repeated within 40 minutes. In those who showed no difference in response between the two challenges (the non-refractory group) hyperventilationinduced asthma was significantly inhibited by cholinergic blockade, which suggests that a vagal reflex mechanism was concerned. In those showing a diminished response to the second challenge (the refractory group) there was no protection from cholinergic blockade, which points to another mechanism, such as release of mast-cell mediators. There was no difference in age, atopic state, clinical severity, sensitivity to hyperventilation, or baseline airway function between the two groups, although the refractory group did show a slower recovery from hyperventilation-induced asthma.

Interpretation of comparisons in bronchoconstrictor response when baseline values vary is always difficult. In the repeated hyperventilation challenges the refractory group had a lower baseline PEFR before the second of the pair of tests but it was these subjects who showed a diminished bronchoconstrictor response, making it unlikely that the difference between the two groups could be explained by a difference in baseline values. After inhalation of ipratropium bromide the bronchodilatation was similar in the two groups and could not therefore account for the difference between them in degree of protection. Using the absolute PEFR values instead of percentage changes made no difference to our results (table). Published data that include both PEFR and FEV , show that the two measurements give similar results. ${ }^{816}$

In previous studies cholinergic antagonists, given in large doses, have been shown to protect (producing at least a $50 \%$ reduction in responses) $40-60 \%$ of $N$ subjects after exercise challenge, although the presence of cholinergic blockade had not been demonstrated by methacholine challenge in many of the studies. ${ }^{48}$ This study shows protection of a similar degree after hyperventilation challenge. Cholinergic blockade has been proved to be ineffective in protecting against exercise-induced asthma ${ }^{17}$ or hyperventilation-induced asthma ${ }^{18}$ when subfreezing air is inhaled but there are no 
published data on the protective effect of atropine in hyperventilation-induced asthma when ambient air temperatures are used.

Cholinergic blockade was found to inhibit exercise-induced asthma only in those subjects in whom airway obstruction affected mainly large airways, as determined by changes in density dependence of maximum expiratory flow, ${ }^{67}$ whereas sodium cromoglycate inhibited those with predominantly small airways obstruction. ${ }^{7}$ These findings may provide an explanation for our results since the non-refractory group may have large airway obstruction, effected by a vagal reflex, whereas the refractory group may have predominantly small airway obstruction, where mediator release is more likely; and it was this latter group that showed a delayed recovery from hyperventilation-induced asthma.

Evidence that mediator release plays a part in exercise-induced asthma is provided by the demonstration of a rise in plasma histamine concentration ${ }^{19}$ and neutrophil chemotactic factor ${ }^{20}$ during and after exercise in asthmatic but not normal subjects. No rise in either plasma histamine ${ }^{19}$ or neutrophil chemotactic factor ${ }^{21}$ has been found in hyperventilation-induced asthma, however, which suggests that the rise in plasma concentrations during exercise may reflect release from basophils rather than from pulmonary mast cells. The failure of venous plasma concentrations of mediators to rise during hyperventilation does not exclude undetected local pulmonary mediator release. Mediators may have a major role in the production of exercise-induced asthma in only a proportion of subjects as not all are protected by cromoglycate ${ }^{10}$ and the inhaled antihistamine clemastine gave a $50 \%$ protection from exercise-induced asthma in only five out of 10 subjects tested. ${ }^{16}$ The reason for the refractory period in exercise-induced asthma is uncertain, but one explanation is that mediators could be released during the first exercise test and time is required for mast cells to regranulate or to recover their response. ${ }^{12}$

In a study by Weiller-Ravell and Godfrey only half the subjects made refractory to exercise by multiple testing responded to a concentration of inhaled allergen that had previously caused airflow obstruction. ${ }^{22}$ This not only is further evidence of a dual mechanism in exercise-induced asthma but suggests that in some subjects exercise-induced asthma and the response to inhaled allergens share a common pathway. It is unlikely that airway muscle becomes refractory to repeated challenge, since the response to histamine challenge during the refractory period is unchanged. ${ }^{23}$

There is much evidence to suggest that exercise- induced asthma and hyperventilation-induced asthma have the same pathogenesis. ${ }^{2313}$ After hyperventilation-induced asthma, however, Stearns et al found no evidence for refractoriness in seven adults with mild asthma, although a refractory period after exercise-induced asthma was observed in the same subjects. ${ }^{13}$ They concluded that mediators were not concerned in the pathogenesis of exercise-induced asthma or hyperventilationinduced asthma and that the refractory period after exercise was caused by the rise in circulating endogenous catecholamines, which activate airway $\beta$-receptors. This explanation is doubtful, since it has been shown that exercise in warm, humid air to prevent bronchoconstriction, presumably giving the same catecholamine response, is not followed by refractoriness. ${ }^{24}$ Furthermore, the plasma catecholamine and cyclic AMP response of asthmatics to exercise appears to be blunted, and as no rise in plasma catecholamines occurs with hyperventilation this is an unlikely explanation. ${ }^{14}$ Our finding of a refractory period after hyperventilation is at variance with the results of Stearns et $a l^{13}$ and may reflect a greater severity of asthma in our subjects. If mediator release plays a part in the airflow obstruction resulting from airway cooling in at least some subjects, it would explain why these subjects are not protected by cholinergic blockade. Cromoglycate may have prevented hyperventilation-induced asthma in this group, but it was not used as there is some doubt whether it acts solely as a mast cell stabiliser and some evidence for its effect on postganglionic cholinergic fibres. ${ }^{25}$

Although the reason for the refractory period remains in doubt, we could divide our subjects into two groups on the basis of their degree of refractoriness to repeated hyperventilation and their protection or lack of protection by cholinergic blockade. This is strong evidence that two mechanisms play a part in hyperventilation-induced asthma even though they may be interrelated (cholinergic stimulation increasing mediator release ${ }^{26}$ and histamine being known to stimulate cholinergic reflexes in vagal afferent pathways ${ }^{27}$ ).

We showed that seven out of nine subjects showed a reproducible degree of refractoriness to repeated hyperventilation on repeated testing; but further studies are needed to look at the short-term and long-term reproducibility and the factors affecting it, as well as the reproducibility of protection by cholinergic agents in hyperventilation-induced asthma. This dual response to airway cooling should, however, be borne in mind in both the treatment and the assessment of agents designed to protect against exercise-induced or hyperventilationinduced asthma. 
We are grateful for financial support to the Asthma Research Council and Napp Laboratories. Dr Neil Pride provided valuable advice.

\section{References}

' Chen WY, Horton DJ. Heat and water loss from the airways and exercise induced asthma. Respiration 1977;34:305-13.

${ }^{2}$ Deal EC, McFadden ER, Ingram RH, Strauss RH, James JJ. Roles of respiratory heat exchange in production of exercise-induced asthma. J Appl Physiol 1979;46:467-75.

${ }^{3}$ Kilham H, Tooley M, Silverman M. Running, walking and hyperventilation causing asthma in children. Thorax 1979;34:582-6.

${ }^{4}$ Simmonsson BC, Skoogh BE, Ekstrom-Jodal B. Exercise-induced airways constriction. Thorax 1972;27:169-80.

${ }^{5}$ Godfrey S, König P. Inhibition of exercise-induced asthma by different pharmacological pathways. Thorax 1976;31:137-43.

${ }^{6}$ McFadden ER, Ingram RH, Haynes RL, Wellman JJ. Predominant site of flow limitation and mechanism of post exertional asthma. J Appl Physiol 1977;42:74652.

7 Thomson NC, Patel KR, Kerr JW. Sodium cromoglycate and ipratropium bromide in exercise-induced asthma. Thorax 1978;33:694-9.

${ }^{8}$ Hartley JPR, Davis BH. Cholinergic blockade in the prevention of exercise-induced asthma. Thorax 1980;35:680-6.

${ }^{9}$ Cox JSG, Altounyan REC. Nature and action of disodium cromoglycate (Lomidal). Respiration 1970;27:292-309.

${ }^{10}$ Anderson S, Seale JP, Ferris L, Schoeffel R, Lindsay DA. An evaluation of pharmacotherapy for exerciseinduced asthma. $J$ Allergy Clin Immunol 1979;64:612-24.

"Edwards AT, Tooley M, Godfrey S. The refractory period after exercise-induced asthma: its duration and relation to severity of exercise. Am Rev Respir Dis 1978;118:247-54.

${ }^{12}$ Nielson EH, Bytzer P, Clausen J, Chakravarty N. Electron microscopic study of the regeneration in vitro of rat peritoneal mast cells after histamine secretion. Cell and Tissue Research 1981;216:635-45.
${ }^{13}$ Stearns DR, McFadden ER, Breslin FJ, Ingram RH Reanalysis of the refractory period in exertional asthma. J Appl Physiol 1981;50:503-8.

${ }^{14}$ Barnes PJ, Brown MJ, Silverman M, Dollery CT. Circulating catecholamines in exercise and hyperventilation induced asthma. Thorax 1981;3:435-41.

is Cockcroft DW, Killian DN, Mellon JJA, Hargreaves FE. Bronchial reactivity to inhaled histamine: a method and clinical survey. Clin Allergy 1977;7:135-243.

${ }^{16}$ Hartley JPR, Nogrady SG. Effect of an inhaled antihistamine on exercise-induced asthma. Thorax 1980;35:675-80.

${ }^{17}$ Deal EC, McFadden ER, Ingram RH, Jaeger JJ. Effects of atropine on the potentiation of exercise-induced bronchospasm by cold air. J Appl Physiol 1978;45:238-43.

${ }^{18}$ Breslin FT, McFadden ER, Ingram RH, Deal EC. Effects of atropine on respiratory heat loss in asthma. J Appl Physiol 1980;48:619-23.

${ }^{19}$ Barnes PJ, Brown MJ. Venous plasma histamine in exercise and hyperventilation induced asthma. Clin Sci 1981;61:159-62.

${ }^{20}$ Lee TH, Nagy L, Welport MJ, Kay AB. Mechanism of exercise-induced asthma. Thorax 1981;36:713 (abstract).

${ }^{21}$ Deal EC, Wasserman SI, Soter NA, Ingram RH, McFadden ER. Evaluation of role played by mediators of immediate hypersensitivity in exerciseinduced asthma. $J$ Clin Invest 1980;65:659-65.

${ }^{22}$ Weiller-Ravell D, Godfrey S. Do exercise- and antigeninduced asthma utilise the same pathway? J Allergy Clin Immunol 1981;67:391-7.

${ }^{23}$ Schoeffel RE, Anderson SD, Gillam I, Lindsay DA. Multiple exercise and histamine challenge in asthmatic patients. Thorax 1980;35:164-70.

${ }^{24}$ Anderson SD, Daviskas E, Schoeffel RE, Unger SF. Prevention of severe exercise induced asthma with hot humid air. Lancet 1979;ii:629.

${ }^{25}$ Harries MG, Parkes PEG, Lessof MH, Orr TSC. Role of bronchial irritant receptors in asthma. Lancet $1981 ; \mathbf{i}: 5-7$.

${ }^{26}$ Kaliner M, Orange RP, Austen KF. Immunological release of histamine and slow reacting substance of anaphylaxis from human lung. IV. Enhancement by cholinergic and alpha-adrenergic receptors. $J$ Exp Med 1972;136:556-67.

${ }^{27}$ Holtzman MJ, Sheller JR, Dimeo M, Nadel JA, Boushey HA. Effect of ganglionic blockade on bronchial reactivity on atopic subjects. Am Rev Respir Dis 1980; 122:17-25. 